\title{
Far from the madding civilization: Anarcho-primitivism and revolt against disintegration in Eugene O'Neill's The Hairy Ape
}

But often, in the world's most crowded streets, But often, in the din of strife, There rises an unspeakable desire After the knowledge of our buried life; A thirst to spend our fire and restless force In tracking out our true, original course. (Matthew Arnold, "The Buried Life")

\author{
Mojtaba Jeihouni \& NASSER MALEKI* \\ Razi University
}

Received: 10/10/2015. Accepted: 19/05/2016.

\begin{abstract}
Anarcho-primitivism contends that modern civilization deprives people of their happiness, which is why it seeks to reconstruct civilization on a primitive basis, one that holds concrete promises of happiness. It argues that a harmonious relation with human nature and external nature needs to be established by translating technological societies into societies that are free of hierarchy, domination, class relationships, and, simply put, of modern structures. Anarcho-primitivists intend to reinstate a primitive outlook in the modern era and recover the authenticity and wholeness lost to the tyranny of civilization. The radical nature of Yank's anti-authoritarianism in Eugene O'Neill's The Hairy Ape (1921) demonstrates that he is totally at a loss about the positive functions of industrialism. We argue that Yank expresses a deep resentment toward civilization that is barely hidden in the play. This leads us to suggest that Yank's objective is not dissimilar from that of anarcho-primitivists: he values his individuality and tries to subvert the social forces that are arrayed against it. Like anarcho-primitivists, he is determined to bring down the pillars of the material culture in favor of a primitive life, where free subjectivity or individuation becomes the integral gift of society.
\end{abstract}

KEYWORDS: The Hairy Ape, Eugene O’Neill, Yank, anarcho-primitivism, civilization, disintegration, revolt.

\footnotetext{
*Address for correspondence: Mojtaba Jeihouni and Nasser Maleki. Department of English Language and Literature, Faculty of Arts, Razi University, 6714967346, Kermanshah, Iran; e-mails: mojtaba.jeihouni@yahoo.com and n.maleki@razi.ac.ir.
} 


\section{INTRODUCTION}

The Enlightenment promoted a rational thinking that assumed culture and reason could triumphantly resolve the problems and tensions of human communities. The Romantics, however, struggled with the idea that a society oblivious to injustice and dogma was conceivable only through the full exercise of reason, revealing the threats cold rationality posed to nature and to human life. Instead, they put their trust in the intuitive, reflecting long and deep on nature and becoming, in the process, "worshipper[s] of Nature" (2005: 115), as Wordsworth says in "Tintern Abbey". The Romantics acutely drew attention to the disappearance of the natural world into a heartless urbanization and industrialization. Their discontent was with the cultural and social conditions which endorsed the submission of nature to the practical interests of man. Different as they were in their attitudes toward politics, they were united in their view that dominance of industrialism over nature implied man's egoistic sense of superiority. With the radical thrust of their ecological awareness, they fervently underscored the non-hierarchal interdependence of human societies and the natural world. In their poetry, they scrutinized the uncoupling of nature and civilization and returning to primal simplicity through the lens of emotional reflection. In William Wordsworth, for example, individuals find solace and contentment not in progress but in steadfast attachment to their immediate environment and the emotions they attribute to it. For the Romantics, human life was inherently connected with nature and not with industry.

Like English Romanticism, American Transcendentalism rebelled against the rampant materialism that had come in vogue in eighteenth century under the Enlightenment's instrumentalist rationality. In its stress on the innate goodness of the individual and nature, Transcendentalism spoke out against the despoiling effects of industrialization. Transcendentalists adopted a utopian outlook of men as able to transcend the material world by means of their spiritual essence and take part in the divine spirit. Henry David Thoreau, who had already stood against the established institutions with On the Duty of Civil Disobedience (1849), took his rebellious, anarchic views to their peak by withdrawing from the bustle of civilized life and living in the woods of Concord, Massachusetts, for two years and two months all alone, the detailed account of which is offered in Walden (1854). Thoreau's insistence on leading a simple life, along with his adoration of nature's intrinsic value, was shared by the fellow Transcendentalist Ralph Waldo Emerson who similarly sought to protect the American citizen from the besetting aspects of civilization.

The primitive orientations of nineteenth century are extended in the late twentieth and early twenty-first centuries through more systematic ecological programs. In the primitivist utopia which these counter-hegemonic projects-most notably anarcho-primitivismdelineate, none of the advanced technologies of the present age would be allowed; in such an idyll, management of one's life would not exceed beyond the employment of simple tools. For anarcho-primitivists, two major crises are at work that make Green and emancipatory 
action necessary. One is the failure of technology, and the second the isolation or the degeneration of people. The first issue is observable in traffic jams, increasing pollution, and destruction of the natural scene. The second problem is evident in mass unemployment, poverty, cynicism, boredom, and psychosomatic breakdowns. Anarcho-primitivists believe that these consequences flow from the materialist rationality of civilization, and thus it is civilization that should be staunchly opposed.

Yet, despite their lack of faith in the modern society and their yearning for reverting to the primitive lifestyle, anarcho-primitivists actually mean to go forward instead of merely sticking to an idealized past. John Zerzan, the famous American anarcho-primitivist, argues that people now distrust the technological aspirations of modern culture, making the point that this has led to increasingly dissatisfied societies. Adopting a radical stance toward this bleak landscape, he maintains, "not only was human life once, and for so long, a state that did not know alienation or domination, but [...] those humans possessed an intelligence at least equal to our own" (2009: 3). According to anarcho-primitivists, humanity should directly address the interrelated social and environmental crises of the present age, arguing that this resistance would open up new ethical horizons for tackling the subjugation of human and non-human nature. Such rationale is expected by its proponents to expose that which the world has subsequently lost through the development of technology. The aim of anarchoprimitivism is then, "to develop a synthesis of primal and contemporary anarchy, a synthesis of the ecologically-focussed [sic], non-statist, anti-authoritarian aspects of primitive lifeways with the most advanced forms of anarchist analysis of power relations" (Moore, 2012: 4).

The Hairy Ape has been among those of O'Neill's early plays to have received considerable critical attention. The greater part of this criticism has bestowed importance upon its expressionism. Critics like Ranald argue that in this play O'Neill "resorts to expressionistic techniques" in order to "make an inarticulate character communicate ideas" (2000: 63). Wainscott calls attention to "the violence, cynicism, and anguish of this early American expressionistic play" (2000: 102). Cardullo observes that O'Neill uses techniques borrowed from the German expressionists to question both his "country's rise to economiccum-martial supremacy and its engineering of what amounted, in effect, to a second Industrial Revolution” (2012: 31). While indeed O’Neill employs expressionistic distortions in his management of form and content in The Hairy Ape, it would be incorrect to assume that this theatricality is simply meant to bring to the fore the protagonist's alienation from society. Accordingly, this article intends to engage in the discourse of anarcho-primitivism in order to show that O'Neill actually digs deeper than that. We argue that Yank wishes not only to escape from his alienation but hopes to secure a natural order unsullied by the sophistications of technological life.

As an anti-hero, Yank does not possess the untouchable qualities which characterize the Greek or the Elizabethan tragic hero. The only way Yank achieves tragic stature is through his unrestrained faith in the superiority of his muscular vigor, something that does not 
accomplish much for him. His fighting spirit is not relieved by any hope or a faith that transcends illusion, failing him in his attempt to get past the modern world he unforgivingly deplores. He may boast of direct involvement in changing the course of his miserable life, but he is virtually incapable of bringing down the walls of injustice and mockery. Yank knows that he cannot cope with the powerful forces that are launched against him-whether they are institutional oppressions or his own indomitable inferiority complex - and that stifle his deepest needs when he sets out to challenge the traumatizing effects of his loneliness. At first, he only beguiles himself that his independence is untouched by his superiors, and actually it is he who controls the movement of civilization: "Because he considers his workplace his 'woild', Yank imagines himself and his labor as independent of 'whoever owns dis [ship]' or 'dem slobs in de first cabin' they're 'just baggage"' (Pfister, 1995: 116). This self-esteem is nevertheless rendered powerless as soon as he encounters the sensitive aristocrat Mildred, an event that proves at the sight of the slightest irregularity his identity is stripped of all signs of certainty. The malfunctions of the technological rationality then doom him to his dreadful fate, inciting him to flaunt his defiance against conditions that are meant to remain inescapable and irremediable. Once the truth is disclosed to Yank, O'Neill addresses the fundamental question of the play: Does Yank even belong to the modern world? Yank is illequipped to catch up with the wild pace of civilization and, being ill-equipped, he cannot develop his potentials in this less-than-promising context. Thus, he is forced to contend with his incurable lack of self-conviction which, O’Neill informs us, flows from technology's diffidence toward the estranged individual.

The Hairy Ape is O'Neill's unguarded and unmasked critique of modern civilization. O'Neill demonstrates that modernity with its relentless pursuit of material progress fails to shield humanity from its lethal consequences. He praises Yank for reaching his hands across the void to find a sustainable hope, a life without the puzzling contradictions that haunt his society. Although Yank's helpless quest for redeeming the lost state of belonging accomplishes nothing in the end, his pitiable efforts for the concretization of a natural order signify, in O'Neill's view, his noble failure for reaching a meaningful life.

We will contend that the intersection of anarcho-primitivism and The Hairy Ape can be significantly shown. In order to arrive at this point, we will argue that although at the time of writing the play there was no such movement as anarcho-primitivism, O'Neill's work offers a criticism that is similar to this radical form of dissent. While other types of anarchism like green syndicalism or socialist anarchism focus on overthrowing capitalism per se, anarchoprimitivism's objective is to dismantle the established order, civilization itself. Our aim is to show that The Hairy Ape, likewise anarcho-primitivism, not only questions capitalism but, on a closer inspection, suggests that it is civilization that needs to be opposed. 


\section{ANARCHISM AND RADICAL PRIMITIVISM}

Anarchism may be too elusive a term to be categorized as a neat and identifiable ideology. However, many commentators have taken the view that an anarchist engagement with society simply consists of eliminating hierarchy, authoritarianism, and centralization (Jun, 2010; Morland, 2004; Newman, 2001). Anarchism is informed by the autonomy of the individual, social justice, affirmation of local and small communities, and the development of organic structures of government. In promoting decentralization of power, anarchism asserts that contemporary societies must be constituted on completely different lines, thus conceptualizing a politics of radical difference. Anarchism, explains Kuhn, "is about a noncompromising struggle against institutions of authority [...] and about the creation and maintenance of social relations that do not reproduce such institutions" (2009: 21).

Despite shared revolutionary and radical aspirations, there are nevertheless substantial differences among various anarchist strands. Anarchist-communism argues that in a stateless, classless society the community holds control over the means of production, and people are attracted to work for motives outside the bonds of wage-labor relations. Anarcho-syndicalism puts emphasis on organizing labor unions which could, through direct action, seize control of industry and administration. By contrast, individualist anarchism is more concerned with an insurrection that does not simply aim at ousting a government from power but, more importantly, at toppling the essential identity that binds a subject to the totality of power relations. Pacifist anarchism eschews violence and militarism and instead commits itself to nonviolence in its rejection of the state. Anarcho-primitivism, the emerging variety of anarchist thought, insists on a primitivist critique of industrial civilization.

In rallying against the excesses of industrialization, anarcho-primitivism is critical of the shift from a primitive manner of life to an unrestrained reliance on technology. It is not a single, self-contained notion, but a combination of supplementary ideologies (e.g. anarchism, Marxism, and psychology) which unanimously express enmity toward - or are, at least, critical of - science, technology, and industry. But anarcho-primitivism is an ecological and political perspective that draws mainly upon primitivism and eco-anarchism. Primitivism is a philosophical position that has characterized the whole Western culture, originating from antiquity and continuing through the medieval era, the Renaissance, the Enlightenment, the Romantic period, and the modern age (Geertz, 2004). It seeks to offer an alternative view, antithetical to the modern vogue of progress, regarding technology and exploitation of nature, arguing that the highest degree of excellence can be achieved by the restoration of the primitive way of life, the ecological community. According to Lovejoy and Boas, primitivism is "the belief of men living in a relatively highly evolved and complex cultural condition that a life far simpler and less sophisticated in some or in all respects is a more desirable life" (1997: 7). It is mainly concerned with explaining how civilization has alienated humans both from themselves and from the external nature. This anti-civilization movement, Aaltola 
points out, "argues that the core elements of contemporary civilization are to blame for current social and environmental problems" (2010: 164) and tries to provide the impetus for a cooperative response to the social and environmental crises and, thus, to hasten the ethical transformation of everyday life.

The other major current that anarcho-primitivism is associated with is eco-anarchism. Coming to prominence in 1970s and 1980s, eco-anarchism, like primitivism, questions the dominant industrial values that underpin the degradation of humanity and nature. Unlike primitivism, however, eco-anarchism explicitly challenges the hierarchal society and argues that the state must be abolished. While primitivism ultimately does not seem unwilling to attune itself to governmental and institutional strategies, eco-anarchism is averse to political compromise, to integration within the state. The transformation of industrial civilization, it argues, could not be achieved merely by reform. With eco-anarchism, therefore, popular struggles and exemplary action gain legitimacy.

In its attempt to widen out the horizons of these two major streams of environmentalism, anarcho-primitivism, as Curran rightly points out, "takes antiauthoritarianism to giddy new heights" (2007: 39). Anarcho-primitivism emerged during the 1980s from the work of Fredy and Lorraine Perlman, John Zerzan, and George Bradford. This radical Green movement does not simply reject the modern state, as eco-anarchism does; rather, it proposes that we put a halt to civilization itself. The state, so its argument runs, simply disguises itself in the hypercomplex, industrial setup of civilization. It is the civilization, or what Zerzan calls "symbolic culture" (2008: 7), that has to be done away with. Shantz notes that anarcho-primitivists "do not simply attribute blame so some singular 'evil,' such as government or technology or religion, but instead show these oppressive systems and structures as an inherent part of civilization" (2010:6). Their point is that the institutions they call into question arose not from modernity, state, or capitalism, but from the civilizing process itself.

Furthermore, anarcho-primitivism seeks to revive the simplicity of life and the compatibility with nature that humanity experienced prior to civilization. It contrasts the disastrous consequences of civilization with the natural advantages of primitive cultures, underscoring the early and allegedly happier life the nomadic people could enjoy. According to anarcho-primitivists, in those times nature was not an object to be domesticated and manipulated. But with the inauguration of symbolic culture, nature began to be objectified, which in turn resulted in the domestication of the individual. This progression, Kintz writes, can be currently seen in the "division of labor, coordination of action, standardization of technique, institution of social and ritual rules, and finally, industrial behavior" (2002: xiii). Anarcho-primitivists use this evidence to argue that the more technology continues to have command over human affairs, the more humanity sinks into the abyss of alienation. What is needed, they suggest, is to perceptively understand the primitive past and reject the 
pathological condition of the present in order to move ahead, toward what Zerzan calls a "future primitive" (2009: 1).

Anarcho-primitivism, as stated by Truscello, holds on to some basic premises: "[T]he 'reform' agenda of the left does not address the root problem of injustice, civilization itself, variously defined; the alienating features of civilization can be located in the advent of agriculture/domestication [...]; agricultural civilization enabled the division of labour and the rise of hierarchical political structures; a form of 'natural anarchy' existed when human lived in hunter-gatherer societies" (2011: 252). This constitutes a significant departure from mainstream forms of ecological thought which frequently concede that civilization and technology can be liberatory if brought into the horizon of anarchist politics. For anarchoprimitivists, negotiation and the forging of consensus with the status quo is simply out of the question.

If the present era is the time of displacement, the modern individual lodges in a space between inertia and despair. Anarcho-primitivists contend that civilization with its insistence on the growth of life in material terms has precipitated the spiritual downfall of humanity. Zerzan argues that civilization has accentuated a cynical sense of loss and anxiety in its subjects. He takes issue with "the fatal emptiness" (2002: 120) rampant in a world devoid of direction, of purpose: "When meaning and desire are too painful, too unpromising to admit or pursue, the accumulating results only add to the catastrophe now unfolding" (2002: 122). In the face of this crisis which is reaching alarming levels, the modern individual finds it difficult to come to grips with his self-definition. Under the all-pervasive pressure of alienation, he cannot aptly express himself, cannot find the existing means of communication efficient, and consequently will not be able to live fruitfully in relation to what Horkheimer describes as the "rationalized irrationality" of civilization by which "nature, in and outside of man, [...] is not really transcended or reconciled but merely repressed" $(2004: 64,65)$.

According to anarcho-primitivists, technology is so implicated in the life of the modern man that it has been granted the license to proceed without limits, becoming an insidious instrument of domination. They argue that accepting technology as a given implies that one has already accepted its laws and its predetermined social relations. In this way, the preservation of technology presupposes the preservation of the individual and finally his adjustment to its requirements ensures the preservation of the system. Stressing the importance of an ecological politics free from the rigid relationships of a conscienceless industrial society, anarcho-primitivism, by contrast, "wants people to become free individuals living in free communities which are interdependent with one another and with the biosphere they inhabit" (Moore, 2012: 9). It puts emphasis on toppling the grand systems - the metanarratives - of modernity in order to establish primitive communities where people would be empowered to abolish the conditions that compel their alienation and develop their creative potentials. Building on the hopes of primitivism for collective self-realization, 
anarcho-primitivism aims at paving the way for people to live as amply as possible without imperiling the freedom of each other in ecologically-centered communities.

\section{THE ABYSS OF NON-BELONGING: EXPRESSING THE INEXPRESSIBLE}

O'Neill at first showed a particular interest in socialist anarchism and enthusiastically read the writings of the celebrated anarchist Emma Goldman. He wrote his first full-length play, The Personal Equation (1915), on anarchism. The play tells the story of Tom and his mistress, Olga Tarnoff, who decide to sabotage the engines of a ship in order to instigate the strike of laborers worldwide. But O'Neill soon recognized that "propaganda had no place in his dramas" (Dowling, 2014: 134), and commitment shifted from communist anarchism, which focuses solely on political mobilization, to philosophical anarchism, an individualist anarchism that puts emphasis on self-mastery and self-constitution. O'Neill adopted philosophical anarchism from Benjamin R. Tucker, a publisher and editor of the anarchist journal Liberty. Tucker promoted change through nonviolent strategies and thus argued against the direct, violent anarchism of Emma Goldman and Alexander Berkman. Although O'Neill remained loyal to the latter despite its failures, it was to the former that he felt most drawn.

Dowling (2007) in his essay "On Eugene O’Neill's 'Philosophical Anarchism"” argues that O'Neill's philosophy consists of three chief principles: aversion to violence, priority of self-emancipation over social emancipation, and commitment to expanding self-emancipation in society. Instead of pinning his hopes on the current institutions for a change, O'Neill shows "complete disregard of all social and political institutions (the press, organized religion, government, law enforcement, the military) as 'phantasms,' 'ghosts,' or 'spooks' to exorcise from one's mind" (Dowling, 2014: 50). From O’Neill's anarchist perspective, anything less than an individual transformation will not do. O'Neill's Nietzschean fury is directed against the destructive effects of society upon individual becoming, and thus he hopes to see revolution fulfilled not through outward anarchy but rather through inner transfiguration. Life is often an "unsuccessful struggle", he stated in an interview in 1922, "for most of us have something within us which prevents us from accomplishing what we dream and desire. [...] I suppose that is one reason why I have come to feel so indifferent toward political and social movements of all kinds" (qtd. in Bigsby, 1982: 42).

What catches the eye most in The Hairy Ape is O'Neill's socialist anarchism. Despite O'Neill's resistance to propaganda, the play resonates with a rejection of capitalism much congenial to the volcanic temperament of Goldman. It is hardly surprising that the play evoked the interest of the FBI at the time, because, according to a government agent, it "possesses more inferential grounds for radical theories than R.U.R. [by Czech playwright 
Karl Capek], which has already been adopted by the radical fraternity" (qtd. in Diggins, 2007: 74). But beyond the surface manifestations of propaganda, O'Neill pries open larger problems inherent in the industrial civilization, illustrating the conflict between civilization and human nature which, in his view, is detrimental to the well-being of humanity. He strips off the veneer of modern experience and reveals the corruption of human nature by civilization. The play is about the modern soul which, deprived of wholeness and unity of experience, cannot live in harmony with the mechanistic development of society. In 1941 O'Neill retrospectively wrote that The Hairy Ape looks beyond labor politics, noting that it is "about Man, the state we are all in of frustrated bewilderment" (Bogard \& Bryer, 1988: 522).

On the basis of O'Neill's own opinion, we can argue that The Hairy Ape is closer in spirit to the anarcho-primitivism that did not even exist during O'Neill's lifetime than socialist anarchism. This claim somewhat finds an echo in the observation of Krasner when he remarks, "In the play modern technology is found wanting; it is the hand of progress, but crushes the humanity it is meant to serve" (2005: 147). Yank's resistance to his social role is characteristic of his consistent rebellion against the horrors of a technology-ridden society, a frozen world in which he cannot even rise to significance, let alone greatness. The engulfing totality that comprises the social reality is simply unbearable for Yank, prompting him to reject the complexity of modern civilization without reservation. In keeping with anarchoprimitivism's promotion of a politics of dissent, Yank's revolt is a response to the "meaningless web of unnatural constraints [...] the organization of repression within the entrails of Leviathan" (Perlman, 1983: 208). O'Neill's hostility to bourgeois civilization clearly dictates the moral logic of The Hairy Ape, and Yank, O'Neill's everyman, is a domesticated individual who pursues a natural freedom unhindered by all forms of technological domination.

Yank's colloquial and distorted speech is a sign of his restive consciousness which is under the siege of inner and outer conflicts. Yank does not feel the compulsion to speak forth as if the addressee were of much significance. He pours out speech, not to appear proper, but to give expression to his needs; and if he fails in this unorthodox path, he will not - cannotmend his ways in subsequent interactions. O'Neill's novel exploration of the American vernacular-or, more precisely, the Brooklyn dialect-is based on the avant-garde observation of the modern man as repressed by the heartless process of civilization. Yank is blatant, careless, inconsiderate, and aggressive in his treatment of the outside world, all of which are the results of the careless rejection he has received from it. The Hairy Ape is set in the 1910s and Yank's anger is a reaction to the depressing circumstances of the Progressive Era when the working class faced a daily struggle for survival, laboring under the most dreadful of conditions. The success of a few ambitious businessmen came at the expense of people who had to live in poverty and squalor. According to Hillstrom, "[t]he wealthy owners of mining operations, steel mills, textile factories, slaughterhouses, and other industrial facilities believed that they had the right to run their businesses as they pleased. Their main 
goal was to earn profits, and their relentless pursuit of this goal often led them to exploit workers" (2010: 55). Being cut off from the joy of life, Yank the laborer therefore yells his existential doubts in order to gain the attention and affection of a consumerist society that has little use for autonomy. And should the final drama of his revolt be imprisonment and death, he is nevertheless ready to take his chances.

Before the appearance of Mildred in scene 3 in the stokehole, Yank is not confronted by malignant nostalgia; he is, on the contrary, jubilant and strong in the face of industrial terrors. Although an exhausting chore, working on the burning stokehole does not rob Yank of his ease. He is of the opinion that the ship "is home" (O'Neill, 2013: 7), and it is he and people like him who run this home with their sweat and blood. Speculations of this sort are prevalent until Yank loses his pride. When robbed of his self-conviction, Yank embarks upon a futile search for his real identity, which he considers to have been something other than his naïve subordination: "Nobody gets me but me, see? I started to tell de Judge and all he says was: 'Toity days to tink it over." Tink it over! Christ, dat's all I been doin' for weeks!" (O’Neill, 2013: 41). O’Neill himself does not regard Yank as one capable of changing the course of his unhappy life the way he wants it. "Yank can't go forward", he says, "and so he tries to go back" (O’Neill, 1990: 61). Trapped in a repressive social system that offers little if any possibility, Yank does not view the horrifying present with inward peace, but he does not hand himself over submissively to his fate either. He cannot content himself with being regarded as a mere tool, his subjectivity being emptied and reduced to nothingness by institutionality. Instead, he devotes all his energies to purify and 'naturalize' the current order in terms of increase in freedom, autonomy of the subject, and equality in social life. Thus, his backward movement reflects his yearning for retrieving his composed self and bridging the gap that divides his natural identity from the historical reality.

In The Hairy Ape O'Neill calls into question the modern values that sap the spiritual strength of the underdog. He is true to his belief that civilization, by employing its logic of domestication, directs the natural impulse of humanity for self-fulfillment to passive acceptance of outside patterns in order to prepare them to fit into a specific form of social setup. In this fraught transaction between the individual and the imperatives of the day, the primitive nature of humanity experiences loss and depression. "The glamorization of the primitive", as Krasner says, is deployed by O'Neill "as a counterintuitive panacea to the overcivilized notion of bourgeois-mechanized-urbanized life" (2012: 267). Yank's only solace, therefore, rests in endurance. He pays a price for his beliefs that can hardly sustain him, carrying on through the city's bleak mist, pushed by a Schopenhauerian will to live, a will to endure humiliation and rejection for the sake of "belonging".

O'Neill delves into Yank's consciousness to illustrate the neurotic condition he is caught in. He stresses the de-centering of the subject in the modern era and, following August Strindberg, raises doubts regarding the Romantic hyperbole of inward power for overcoming modern fragmentation. For O'Neill and Strindberg, the repressive barriers of outside reality 
dismantle individual vivacity and trigger insurmountable desolation, restless wandering, and futile communication. O'Neill's aim in his expressionist plays, such as The Hairy Ape, is to find a way of expressing the most latent of spiritual tensions, but he is "always aware that the darkly inexpressible cannot be expressed" (Berlin, 2000: 94). In The Hairy Ape surface reality is distorted so that we could see the world as it appears to Yank's troubled mind. As a typical expressionist character, Yank represents the frustrated agency of his class, yet he does not prove to be quite a worthy spokesperson. This is because, despite all his attempts to verbalize the wrenching sense of alienation that encroaches on him and his class, he is unable to make his voice heard, pretty much like the deformed figure in Edvard Munch's painting The Scream. In sum, O’Neillian expressionism has four major characteristics which, as Walker contends, crack open the homogeneous surface of modern society: "(1) a central character (often an anti-hero) who functions as a figure for the artist, (2) an agon between the central artist figure and the forces of commerce and industry, (3) the theme of technology as a source of spiritual malaise, and (4) a formal disarticulation of the play's verbal, vocal, and pantomimic languages" (2005: 120).

Yank is pushed to the state of non-belonging for his attempts to grasp his place in history, a place he ultimately understands is teleologically structured by symbolic culture. $\mathrm{He}$ is marooned in isolation because he considers his work an extension of his ego; and once he steps outside his work, he observes that he has no identity, no center to fall back on, no "I" to call his own, nothing but a loose bundle of energies that leads nowhere: "Steel was me, and I owned de woild. Now I ain't steel, and de woild owns me. Aw, hell! I can't see-it's all dark, get me? It's all wrong!" (O’Neill, 2013: 52). For O’Neill, Yank is a man "who has lost his old harmony with nature, the harmony which he used to have as an animal and has not yet acquired in a spiritual way" (O’Neill, 1990: 61). Yank is so dissolved in his work that losing the self-esteem he naïvely associates with it forces him into nothingness, that sort of irreconcilable and absurd nothingness where dreams and illusions fail to keep up for long. To be sure, Yank does not wish to have a job simply for providing a living; he covets a job in which he can live.

When civilization deprives him of his autonomy, Yank becomes a disappointed idealist, putting to test various options to express his suppressed self before those who have forced this condition upon him. If he unleashes his beastly qualities, however, it is because he is denied self-manifestation and also because he finds, to his greatest dismay, that he is out-ofjoint with the urban environment. He is crushed by the weight of being recognized as "the filthy beast" or "a hairy ape" (O’Neill, 2013: 24, 29) and by the awareness that he has no choice but to behave accordingly. Thus, he avoids anything that savors of the civilized codes of behavior. He takes action, yet even that action fails to penetrate into the heart of the problem. It only results in his further separation from the society he once supposed he belonged to. Now the door of the zoo cage is open to him as his only shelter. 
As soon as he goes to the gorilla, he is assured that he does not have the slightest hope of being a human citizen anymore. He is convinced by then that if he is to find sympathy and understanding he has to look for it not among men, but among animals. The techno-industrial system (represented in the play by the president of Steel Trust Douglas, his daughter Mildred, and the crowd in Fifth Avenue) topples the very foundations of his beliefs, compelling an allenveloping transformation of his worldview. The system comes to function as a horrendous reminder that he has succumbed to objectification and helped spread the totalities of civilization without knowing it. But before this epiphany reveals itself to him in its full magnitude, Yank misguidedly - and innocently - tries to attract the attention of a selfabsorbed crowd in Fifth Avenue: "Pointing to a skyscraper across the street which is in process of construction —with bravado.] See dat building goin' up dere? See de steel work? Steel, dat's me! Youse guys live on it and tink yuh're somep'n. But I'm IN it, see! I'm de hoistin' engine dat makes it go up!" (O’Neill, 2013: 37-38). Yank is here caught up in his public identity as a defender of progress, believing that it is in him that others can witness the flawless intimacy of humans and machines.

O'Neill, however, suggests no such intimacy is possible. Thus, when Yank is shaken off from his illusions, he observes the "fear, revulsion, and horror" (Benjamin, 2007: 174) of the big city and grows fragmented. At this point, his estrangement from himself instigates his estrangement from others. Anarcho-primitivists criticize the ill effects of this disintegrating process that the modern man passes through. According to McQuinn, anarcho-primitivism critiques the ways society "systematically alienates our life-activities and denies our desires for a more unitary and satisfying way of life" (2009: 16). O’Neill digs right down to the soul of Yank and his tragic disintegration: "Christ, where do I get off at? Where do I fit in?" (2013: 56). Even though he is too proud to admit it verbally, Yank seeks the primitive, noncalculative form of love from anybody who might offer it. Deprived of all support and sympathy in a mechanical world where human interactions are evaluated based on the unfeeling logic of give-and-take, he concludes that he can only find peace in the territory with which everybody associates him: the animal world.

In The Hairy Ape the large-scale internalization of modern values comes under assail. O'Neill finds fault with the diffusion of these values that keep the reflective consciousness of subjects at bay and produce subjects to be mere obedient effects. From his viewpoint, Yank deserves recognition because he makes a clean break from the technological society with the aim of returning to an undomesticated way of living in a society which Sahlins describes as "the original affluent society" (1972: 1). He refuses to yield to the prevailing dictates of conformity, of objectification. But from that point on he has to move haltingly; he is disengaged from civilization but with no avail. His simple understanding of the world then buckles under the strain of social factors, leaving him marooned with an experience of alienation that encroaches upon his subjectivity. With a revolutionary advice that continues heeded, he flees for comfort to his original state, the primitive life. 
In scene 1, Yank's fellow worker Paddy is shown to be fed up with the status quo. He tells other workers that the traditional seafaring provided sailors with freedom and happiness, ideals which are presently only a myth. Formerly workers on the ship were not slaves, belonging to something outside their own selves, and although they had to work hard, "who'd mind that at all?" (O’Neill, 2013: 10). For Paddy everything now is in a state of chaos; smoke and coal dust are choking the lungs of the hapless sailors. These speculations are of no consequence to Yank as he mocks the old school: "Yuh don't belong no more [...] Yuh're too old" (O’Neill, 2013: 11). Yank, however, gradually comes to embrace Paddy's protest against the circumstances that destroy body and soul. He too realizes that the current mode of life in and out of the ship does not hold any happiness for individuals, whose future is confiscated and kept under control by a deterministic culture. In achieving pseudoindependence, Yank nevertheless separates himself from others. He declares war against the technological ethos and its mind-wrenching influences, cleaving instead to the primitive lifestyle, a way of living that would bestow freedom and happiness upon the individual. Yank dedicates his life to liberation from all shackles that thwart his movement; yet, with every move he is more assured of the strength of the barrier. Stranded in a spiritual morass, "the 'hairy ape,' who has lost his sense of 'belonging,' tries to find his place in a hostile universe which rejects him to the last" (Ranald, 2000: 63).

The Hairy Ape has parallels with one of the outstanding scenes of Strindberg's $A$ Dream Play (1901), the scene in which Indra's daughter descends and sees Coal-Heavers and their miserable lot. In The Hairy Ape the daughter of the President of the Steel Trust descends from her luxurious first-class cabin to the dark stokehole in order to have a glimpse of the laborers' circumstances. However, her entrance, unlike the Daughter's heavenly descent which promises redemption, nips all hopes in the bud and "hurls Yank into an existential crisis" (Beard, 2005: 62). The Hairy Ape is in this sense a dream-like play, and Yank, the object of Mildred's greatest repulsion, awakens from a series of nightmares only to die symbolically. Like the Coal-Heavers, he emotionally backs up his dreams to escape an insupportable reality and find perfection and peace, but, in contrast to them, he cannot hope that anybody might understand his plight as he understands it.

Along similar lines, most of O’Neill's characters are motivated by their obsession with freedom, dreaming of putting an irremediable past behind them and reinventing themselves in the dreary route to self-realization. They are all carried away by some romantic ideal which in the long run lays its predatory hands upon them. In O'Neill, the ideal begs to be unhinged from the real and is thus unwillingly at war with it; what is particular wrestles with what is common; what pulls individuals up fights with what drags them down. Out of this struggle tragedy is born. "It is the dream that keeps us fighting, willing - living", O'Neill said in an early interview. "A man wills his own defeat when he pursues the unattainable. But his struggle is his success! [...] Such a figure is necessary tragic" (Mullett, 1990: 37; emphasis in original). The tragic dimension of The Hairy Ape surfaces in this foredoomed pursuit of "the 
unattainable". Yank takes up the colossal task of overcoming his loneliness in an era which insatiably feeds on this vulnerability. The feeling of insecurity triggered by this condition is the underlying motive for Yank's disintegration, but what additionally contributes to his breakdown is his knowledge of the impossibility, in every sense of the term, of integration in a mechanical world that discards his dreams like rubbish. He is acutely made aware that he is a worthless cog in the wheel of industrial progress.

In his stage directions for scene 1 O'Neill pictures the cramped stokehole as “imprisoned by white steel" (2013: 4). Yank ironically reaps pleasure from his captivity. It is only in scene 6 when he is imprisoned for his breach of law that he suddenly awakens from his dream, shaking the bars and crying out: "Dis is de zoo" (O'Neill, 2013: 39). As soon as the cold hand of reality gets hold of him, Yank descends to the lowest position in which he himself concedes that he is "a hairy ape" to whom the upper classes are "de garbage", "de ashes" the stokers dump over the side (O'Neill, 2013: 40, 38). For all the humiliation that he receives from others, he rejects the instrumentalist rationality of capitalism to the last and assumes responsibility to immunize himself against the conformist conduct. Modern man, Zerzan maintains, should honor his "responsibility to stop the engine of destruction. Passivity, like a defeated attitude, will not bring forth deliverance" (2008: 117). Following the anarcho-primitivist imperative, Yank is bent upon changing his future - actually by going back to an untainted naturalness - feebly gratifying in this pilgrimage his need for selfexpression, for refusal of materialism, for being a constitutive part of the macrocosm. He is thus radically forced into a process of covert introspection which in turn culminates in overt action. Yet, if none of his aspirations materializes and if none of his outbursts attracts any audience, they reveal that his threatening heterogeneity is deep within only a longing for belonging.

\section{YANK AND REVOLT AGAINST THE PILLARS OF SOCIETY}

Anarcho-primitivism does not simply demand a displacement of the reigning hegemony but insists on transforming the art of living itself. Picturing the prospects of natural resurrection, it demonstrates the dangers of civilization and anticipates freedom from the horrors of this absolute loss. But it develops a distinctly novel direction in comparison with, say, primitivism. As Curran observes, "[a]n unyielding anti-authoritarianism and a pursuit of the principles and practices of egalitarianism and mutual aid, gives primitivism its anarchism" (2007: 40). Primitivism, anarcho-primitivism claims, follows a narrowly-focused path, gazing upon the possibility of returning to nature without adequately addressing the matter of power relations which could potentially render any resistance useless. This point distinguishes anarcho-primitivism from primitivism and mainstream environmentalism, for anarcho- 
primitivism "seeks to draw inspiration from it [primitivism], but only insofar as it does not contradict the most far-reaching anarchist analysis - analyses which seek an exponential exposure of power relations in whatever form they take" (Moore, 2009: 5). In other words, anarcho-primitivism places the exhaustive dissolution of hierarchy at the center of its project. It attempts to restore individual autonomy and integrity in the face of power relations that derail individuation and subjectivity in complex ways. Civilization's greatest sin, anarchoprimitivists assert, is that it severs human beings from their original nature as autonomous, creative beings. To deliver themselves from its trespasses, humans must maintain the status of resistance against it.

As Chura says, "[i]n The Hairy Ape ostensibly progressive social forces become agents of a harmful assault on lower-class selfhood" (2005: 130). What is under the fire of Yank is this bogus form of individuality suitably collectivized and otherwise resistant to any change. That Yank dares to consider such subordination inherently revisable makes him an anarchoprimitivist. Firstly, he stands by his rights against the values of civilization. He throws off his chains to enjoy the benefits of a free life, one that is unthreatened by the established belief system which is basically offensive to his dignity as a self-directing subject. Secondly, he can no longer breathe with the odor of technology in the air anymore. At the beginning of the play, he is confident about his presence in the ship, content to remain caught up in the vortex of social docility. Yet, neither his confidence nor his satisfaction lasts long, as his pointless existence begins to weigh upon him, turning him into a full-blooded anarchist. From then on he shakes his fist at the industrial society:

SECRETARY - [Sharply.] Just what was it made you want to join us? Come out with that straight.

YANK - Yuh call me? Well, I got noive, too! Here's my hand. Yuh wanter blow tings up, don't yuh? Well, dat's me! I belong!

SECRETARY - [With pretended carelessness.] You mean change the unequal conditions of society by legitimate direct action —or with dynamite?

YANK —Dynamite! Blow it offen de oith-steel-all de cages - all de factories, steamers, buildings, jails—de Steel Trust and all dat makes it go. (O’Neill, 2013: 50)

Yank's intellectual development shows that he cannot admit of being an accident in the symbolic culture's road to the good life. If civilization reduces all thought to its own image, then Yank is the resisting agent to the administration of subjects as mere objects. But he falls under the spell of a deceptive autonomy with the growing rift between him and the society. He is actually broken to pieces in his clash with the world he wants to transform, and at this point begins his dream-like journey to gather all the pieces of his disintegrated self and make an entire whole of himself again. Under the strain of an intense despair, he ironically criticizes a policeman who, like others, covers up the sordid spectacle of his homelessness: "I 
was born, see? Sure, dat's de charge. Write it in de blotter" (O’Neill, 2013: 52). Disengaged from his mythical self-conceptions, he enters an unknown world to which he does not belong, groping in vain to find his lost self amidst the harrowing circumstances that uproot him from his real self. Beard notes that every external element "supports Yank's subjective view of the world as a dangerous place", drawing the conclusion that "he is [...] a man without a place, and [that] O'Neill is interested in the fate of that alienated individual" (2005: 63). What intensifies Yank's bitterness against the social mores is the awareness that it is not individuals he is up against but a highly organized system of tyranny or, in the words of Eagleton, society's "complex systemic operations" (1991: 37). Furthermore, he is naturally fierce and sensitive, prone to ferocious behavior whenever the question of his authority comes up. Thus, when the lofty indifference of Mildred to his sufferings engenders an enveloping paranoia within him, it simultaneously helps to trigger the full expression of his anger, bringing with it some vague hope that he can reassert his image as the authority. But all that remains for him in the end is to find himself "on a long day's journey into night" (Mann, 2009: 16).

O'Neill exposes the tottering functionality of civilization's exalted idealism and the dehumanizing effects it produces among a downcast people who cannot transcend the insufferable reality and thus fail to live up to their own expectations. In The Hairy Ape he introduces a hero - or, better, an anti-hero-whose self-confidence is ripped to shreds by an anti-essentialist culture that averts its eyes from the genuine needs of human nature. Yank's rage is pointed at this process of denaturalization, this logic of "disintegration", which the enterprise of civilization takes up for fragmenting human subjects. No part of this materialist system is safe from Yank's revolt and no authority above his reproach. He moves resolutely toward fulfillment, positively responding to what anarcho-primitivists consider his natural bent for well-being, and his heated emotions do not cool off at the sight of the growing obstacles he has to overcome. In order to guarantee himself a future, Yank is prepared to brave the unknown whatever the risks, and this results in a disastrous confrontation with the industrial society.

As an anarcho-primitivist, Yank speaks up for freedom from the grips of industrialism, setting his heart on the belief that with his unwillingness to capitulate he would be able to advocate his nature-oriented discourse and help bring down the pillars of symbolic culture. O'Neill's attitude in The Hairy Ape, Alexander points out, is one of "individualist anarchism that sees the structure of society as evil, [and] assumes therefore that any social structure will be evil" (1954: 354). She argues that the play endorses O’Neill's view that civilization and a condition of loss go lamentably together, and salvation would be attained only when we "destroy the status quo" (1954: 354). This observation illustrates the affinity between O’Neill's philosophical anarchism and anarcho-primitivism: consistent resistance against all institutions of authority. For if we put aside Yank's accommodation with the violent action ethos, about which both anarchisms harbor a deep-seated suspicion, his antipathy toward the 
institutionalized society in the teeth of all counter-measures is indeed what both entirely espouse.

Enmeshed in the tight webs of the dominant culture, Yank finds no release from his anguish, which drives him to irrevocable excess. In other words, the more he fails in his endeavors, the more his vulnerable rationality opens the gate for irrationality to nourish his paranoid cynicism. As his life draws to a close, however, he is eventually made to come to terms with his surroundings. He is allowed to "belong" to some place but, tragically, it is only the zoo of civilization where the free spirit is caged. Peace comes only at this moment of revelation, when he recognizes that he never was - nor could ever dream to be - the master of his own destiny under the punitive sway of the techno-capital system. And it is only death, as Dowling puts it, that "provides his sole escape from the cages thrown up around him by modern times" (2014: 243). The encounter with the caged gorilla conjures Yank's most eloquent powers, showing that his dreams for fulfillment - although dashed to piecesremain pure up to the end: 'On'y yuh're lucky, see? Yuh don't belong wit 'em and yuh know it. But me, I belong wit 'em—-but I don't, see? Dey don't belong wit me, dat's what. [...] Youse can sit and dope dream in de past, green woods, de jungle and de rest of it. Den yuh belong and dey don't. [...] But me-I ain't got no past to tink in, nor nothin' dat's comin', on'y what's now — and dat don't belong" (O'Neill, 2013: 55). For O'Neill, individuation stubbornly persists to be an improbability in the modern context, and, like anarchoprimitivists, he launches his critique on this improbability.

\section{CONCLUSION}

While the radical remaking of the given social order may prove to be too much of a problem, it is nonetheless possible, anarcho-primitivists argue, to construct a future society free from the civilizing process. They call for an unconditional resistance in the face of the global hegemony of techno-industrial politics. People should act on the principle that civilization is infected at its roots, thus proposing nothing less than a revolutionary transformation which would put the entire system out of business. According to anarcho-primitivists, reconciliation of man with himself can and must be achieved; for, despite occupying a position of transcendence, civilization inadvertently allows one to undo the dire effects of technological manipulation and expand the scope of his self-recognition. Through this liberation, the individual will no longer feel alone in a city where he and others are presently "alone together", where they "simply accept the urban reality and try to adjust to it" (Zerzan, 2008: $38-45)$.

From the standpoint of anarcho-primitivism, O'Neill in The Hairy Ape upbraids modern culture for driving men into existential solitude and despair. We argued that Yank is 
driven to the margins for holding on to his individuality against a homogenizing system that clamors for conformity. As he fails to accomplish his object for communication, he begins to ponder over the problems which civilization has forced upon him, concluding that he cannot single-handedly call its prerogatives into question. Modern society puts docility of subjects at the forefront of its priorities, and this society, in O'Neill's view, would mercilessly drag a dreamer such as Yank, who craves for an untainted individuality, out of his dreams. The experience leaves him fragile and desperately exposed. "When his worldview is challenged", Beard observes, "Yank's philosophy fails him like a house of straw unable to withstand any threatening wind" (2005: 62). Inflexibility of symbolic culture toward human nature, along with the pervasive presence of objectified subjects, naturalizes the technological reality, preventing Yank from integrating into a primitive community, an ideal for which he readily lays down his life.

\section{ACKNOWLEDGEMENTS}

The present article has benefitted greatly from the suggestions of its two anonymous reviewers. We would like to thank them for their insightful comments.

\section{REFERENCES}

Aaltola, E. (2010). Green anarchy: Deep ecology and primitivism. In B. Franks \& M. Wilson (Eds.), Anarchism and moral philosophy (pp. 161-185). New York, NY: Palgrave Macmillan.

Alexander, D. M. (1954). Eugene O'Neill as social critic. American Quarterly, 6(4), 349-363.

Beard, D. M. T. (2005). American experimentalism, American expressionism, and early O'Neill. In D. Krasner (Ed.), A companion to twentieth-century American drama (pp. 53-68). Malden, MA: Blackwell.

Benjamin, W. (2007). On some motifs in Baudelaire. In H. Arendt (Ed.), Illuminations: Essays and reflections (pp. 155-200). New York, NY: Schocken Books.

Berlin, N. (2000). The late plays. In M. Manheim (Ed.), The Cambridge companion to Eugene O’Neill (pp. 82-95). Cambridge: Cambridge University Press.

Bigsby, C. W. E. (1982). A critical introduction to twentieth-century American drama: 1900-1940. Cambridge: Cambridge University Press.

Bogard, T. \& Bryer, J. (1988). Selected letters of Eugene O'Neill. New Haven, CT: Yale University Press.

Cardullo, R. J. (2012). Eugene O'Neill's The hairy ape in relation to Greek tragedy, Italian futurism, and divine comedy. Moderna Språk, 2, 25-41.

Chura, P. (2005). Downclassing journeys in American literature from Herman Melville to Richard Wright. New York, NY: Routledge.

Curran, G. (2007). $21^{\text {st }}$ century dissent: Anarchism, anti-globalization and environmentalism. New York, NY: Palgrave Macmillan.

Diggins, J. P. (2007). Eugene O'Neill's America: Desire under democracy. Chicago, IL: The University of Chicago Press.

Dowling, R. M. (2007). On Eugene O'Neill's “philosophical anarchism”. The Eugene O'Neill Review, $29,50-72$. 
Dowling, R. M. (2014). Eugene O'Neill: A life in four acts. New Haven, CT: Yale University Press. Eagleton, T. (1991). Ideology: An introduction. London: Verso.

Geertz, A. W. (2004). Can we move beyond primitivism? On recovering the indigenes of indigenous religions in the academic study of religion. In J. K. Olupona (Ed.), Beyond primitivism: indigenous religious traditions and modernity (pp. 37-70). New York, NY: Routledge.

Hillstrom, L. C. (2010). Defining moments: The muckrakers and the progressive era. Detroit, MI: Omnigraphics.

Horkheimer, M. (2004). Eclipse of reason. London: Continuum.

Jun, N. (2010). Anarchist philosophy: Past, problems, and prospects. In B. Franks \& M. Wilson (Eds.), Anarchism and moral philosophy (pp. 45-66). New York, NY: Palgrave Macmillan.

Kintz, T. (2002). Introduction. In J. Zerzan (Ed.), Running on emptiness: The pathology of civilization (pp. viii-Xviii). Los Angeles, CA: Feral House.

Krasner, D. (2005). Eugene O’Neill: American drama and American modernism. In D. Krasner (Ed.), A companion to twentieth-century American drama (pp. 142-158). Malden, MA: Blackwell.

Krasner, D. (2012). A history of modern drama: Volume 1. Malden, MA: Wiley-Blackwell.

Kuhn, G. (2009). Anarchism, postmodernity, and poststructuralism. In R. Amster, A. DeLeon, L. A. Fernández, A. J. Nocella II \& D. Shannon (Eds.), Contemporary anarchist studies: An introductory anthology of anarchy in the academy (pp. 18-25). New York, NY: Routledge.

Lovejoy, A. O. \& Boas, G. (1997). Primitivism and related ideas in antiquity. Baltimore, MD: The Johns Hopkins University Press.

Mann, B. J. (2009). O'Neill's "presence" in Long day's journey into night. In H. Bloom (Ed.), Bloom's modern critical interpretations: Eugene O'Neill's Long day's journey into nightNew Edition (pp. 7-18). New York, NY: Chelsea House.

McQuinn, J. (2009, February 21). Why I am not a primitivist. In A dialog on primitivism (pp. 10-17). Retrieved September 29, 2016 from http://theanarchistlibrary.org/library/various-authors-adialog-on-primitivism.lt.pdf.

Moore, J. (2009, December 12). Comin' home: Defining anarcho-primitivism. Retrieved September 29, 2016 from http://theanarchistlibrary.org/library/john-moore-comin-home-defining-anarchoprimitivism.pdf.

Moore, J. (2012, May 21). A primitivist primer. Retrieved September 29, 2016 from http://theanarchistlibrary.org/library/john-moore-a-primitivist-primer.pdf.

Morland, D. (2004). Anti-capitalism and poststructuralist anarchism. In J. Purkis \& J. Bowen (Eds.), Changing anarchism: Anarchist theory and practice in a global age (pp. 23-38). Manchester: Manchester University Press.

Mullett, M. B. (1990). The extraordinary story of Eugene O'Neill. In M. W. Estrin (Ed.), Conversations with Eugene O'Neill (pp. 26-37). Jackson, MS: University Press of Mississippi.

Newman, S. (2001). From Bakunin to Lacan: Anti-authoritarianism and the dislocation of power. Lanham, MD: Lexington Books.

O’Neill, E. (1990). Eugene O'Neill talks of his own and the plays of others. In M. W. Estrin (Ed.), Conversations with Eugene O'Neill (pp. 60-63). Jackson, MS: University Press of Mississippi.

O'Neill, E. (2013). The hairy ape: A comedy of ancient and modern life in eight scenes. Pennsylvania, PA: The Pennsylvania State University Press.

Perlman, F. (1983). Against his-story, against Leviathan! Detroit, MI: Black and Red.

Pfister, J. (1995). Staging depth: Eugene O'Neill and the politics of psychological discourse. Chapel Hill, NC: The University of North Carolina Press.

Ranald, M. L. (2000). From trial to triumph (1913-1924): The early plays. In M. Manheim (Ed.), The Cambridge companion to Eugene O'Neill (pp. 51-68). Cambridge: Cambridge University Press.

Sahlins, M. (1972). Stone age economics. Chicago, IL: Chicago University Press.

Shantz, J. (2010). Introduction. In J. Shantz (Ed.), A creative passion: Anarchism and culture (pp. 113). Newcastle: Cambridge Scholars.

Truscello, M. (2011). Imperfect necessity and the mechanical continuation of everyday life: A postanarchist politics of technology. In D. Rousselle \& S. Evren (Eds.), Post-anarchism: A reader (pp. 250-259). New York, NY: Pluto Press.

(C) Servicio de Publicaciones. Universidad de Murcia. All rights reserved. IJES, vol. 16 (2), 2016, pp. 61-80 Print ISSN: 1578-7044; Online ISSN: 1989-6131 
Wainscott, R. (2000). Notable American stage productions. In M. Manheim (Ed.), The Cambridge companion to Eugene O'Neill (pp. 96-115). Cambridge: Cambridge University Press.

Walker, J. A. (2005). Expressionism and modernism in the American theatre: Bodies, voices, words. Cambridge: Cambridge University Press.

Wordsworth, W. \& Coleridge, S. T. (2005). Lyrical ballads. (R. L. Brett \& A. R. Jones, Eds.). New York, NY: Routledge.

Zerzan, J. (2002). Running on emptiness: The pathology of civilization. Los Angeles, CA: Feral House.

Zerzan, J. (2008). Twilight of the machines. Port Townsend, WA: Feral House.

Zerzan, J. (2009, February 12). Future primitive. Retrieved September 29, 2016 from http://theanarchistlibrary.org/library/john-zerzan-future-primitive.pdf. 